\title{
Meningkatkan hasil belajar peserta didik dengan menggunakan E-modul berbasis 3D pageflip professional dengan model discovery learning (A useful learning E-modul based 3D pageflip professional with use discovery learning model)
}

\author{
Nadhiifa Eka Asmarani, Mohammad Arief *, Madziatul Churiyah \\ Universitas Negeri Malang, Jl. Semarang No. 5 Malang, Jawa Timur, Indonesia \\ *Penulis korespondensi, Surel: mohammad.arief.fe@um.ac.id
}

Paper received: 2-1-2021; revised: 23-1-2021; accepted: 30-1-2021

\begin{abstract}
Abstrak
Pandemi covid-19 yang sedang melanda berbagai negara termasuk Indonesia telah mempengaruhi berbagai aspek kehidupan salah satunya yaitu pendidikan, dampak dari adanya covid-19, saat ini pembelajaran dilakukan secara daring (online) dan tatap muka secara bergiliran. Sehingga guru dituntut untuk kreatif mengoptimalkan teknologi dalam kegiatan pembelajaran. Oleh karena itu, penelitian ini bertujuan untuk menghasilkan E-modul berbasis 3D PageFlip Professional dengan Model Discovery Learning pada Mata Pelajaran Administrasi Umum untuk meningkatkan hasil belajar peserta didik. Produk e-modul ini berisi pembahasan materi dan soal-soal serta dilengkapi menu Mari Mengamati hingga Mari Menyimpulkan. E-modul ini bisa diakses offline melalui Personal Computer/Laptop dengan Aplikasi 3D PageFlip Professional atau secara online melalui HP Android. Penelitian dan pengembangan ini menggunakan model Research and Development Borg and Gall yang telah dimodifikasi. Teknik analisis data yang digunakan adalah deskriptif persentase dan uji independent sample t-test. Hasil penelitian dan pengembangan ini adalah E-modul berbasis 3D PageFlip Professional dengan Model Discovery Learning pada Mata Pelajaran Administrasi Umum Kompetensi Dasar Bentuk Struktur Organisasi dan Fungsi Manajemen yang telah dinyatakan sangat valid dan layak digunakan dalam pembelajaran kearsipan oleh ahli media, ahli materi, dan 6 peserta didik uji coba kelompok kecil serta terbukti dapat meningkatkan hasil belajar secara signifikan pada uji coba kelompok besar. Sehingga dapat disimpulkan bahwa E-Modul Administrasi Umum layak dan efektif digunakan sebagai bahan pembelajaran untuk meningkatkan hasil belajar peserta didik pada mata pelajaran administrasi umum.
\end{abstract}

Kata kunci: penelitian dan pengembangan; media pembelajaran; e-modul, 3d pageflip; discovery learning, administrasi umum

\section{Pendahuluan}

Corona Virus Disease 2019 (Covid-19) pada saat ini tengah melanda berbagai negara di belahan dunia termasuk Indonesia. Penyebaran virus ini terjadi antar manusia yang secara cepat dan meluas (Kennedy and Suhendarto, 2020; Krishnamurthy, 2020). Sehingga dalam aspek pendidikan diberlakukannya kegiatan Pembelajaran Jarak Jauh (PJJ) dan tatap muka secara bergiliran. Hafshah, dkk (2016) menjelaskan bahwa pendidik dalam menyampaikan materi kepada peserta didik harus dilakukan dengan menggunakan metode dan bahan ajar yang sesuai agar proses belajar dapat terlaksana dengan baik untuk hasil belajar yang maksimal pula. Peserta didik diharapkan dapat memperoleh hasil belajar yang maksimal dengan cara menumbuhkan minat dan kemampuan belajarnya baik secara individu maupun kelompok. Maka dari itu guru harus bisa menerapkannya dalam proses pembelajaran, salah satunya dengan menggunakan media bahan ajar.

This work is licensed under a Creative Commons Attribution-ShareAlike 4.0 International License. 
Kegiatan pembelajaran di Era Industri 4.0 ini menuntut pendidik untuk lebih kreatif dan inovatif menggunakan teknologi dalam pembelajaran. Perkembangan bahan ajar diharapkan bisa berjalan sesuai dengan perkembangan teknologi saat ini. Maka dari itu untuk memaksimalkan hasil belajar peserta didik dan kemampuan belajarnya bisa dilakukan dengan bantuan teknologi. Teknologi digunakan untuk mempermudah jalannya proses belajar dan juga untuk menarik motivasi belajar peserta didik. Oleh karena itu, perlu kreativitas dan inovasi dalam penggunaan media pembelajaran khususnya pada bahan ajar yaitu dengan membuat modul dengan bantuan software yang bernama 3D PageFlip Professional.

Kondisi nyata yang ada di lapangan yaitu guru belum bisa memaksimalkan pemanfaatan teknologi yang ada dalam pembelajaran dan kurangnya pengetahuan guru mengenai bahan ajar elektronik yang mana lebih menarik untuk diterapkan dalam pembelajaran. Tantangan digitalisasi media dalam bidang pendidikan juga menjadi faktor untuk lebih kreatif dan inovatif dalam menciptakan media pembelajaran. Permasalahan yang terjadi yaitu penyampaian materi pembelajaran yang masih menggunakan media konvensional dan minimnya sumber bahan ajar menjadikan guru kurang bisa menyampaikan materi secara maksimal pada peserta didik. Oleh karena itu, sangat penting untuk guru menggunakan bahan ajar yang efektif dan bisa memanfaatkan teknologi dalam proses menyampaikan materi dan memiliki daya tarik bagi peserta didik sehingga dapat membuat peserta didik belajar mandiri dan dapat meningkatkan hasil belajar dengan kondisi yang mudah dan menyenangkan.

Selain penyajian dari bahan ajar yang menarik, diperlukan penerapan model pembelajaran yang tepat. Pembelajaran berdasarkan kurikulum 2013 sangat disarankan menggunakan pendekatan saintifik yaitu mengorganisir pengalaman belajar secara berurutan yang logis meliputi mengamati, bertanya, mengumpulkan informasi, menalar, dan mengkomunikasikan (Permendikbud, 2016). Discovery learning merupakan model pembelajaran yang mendorong siswa untuk belajar sendiri (Baharuddin \& Wahyuni, 2015). Berdasarkan hasil wawancara studi pendahuluan yang dilakukan peneliti dengan Guru Administrasi Umum SMKN 2 Kediri yaitu Bapak Hernanto Baskoro Putro pada tanggal 17 September 2020 bahwa dalam pelaksanaan pembelajaran administrasi umum di masa pandemi ini dilakukan dengan tatap muka secara bergiliran, hal ini dilakukan karena beberapa alasan salah satunya adalah untuk mematuhi peraturan protocol kesehatan yang berlaku di masa pandemi ini.

Pembelajaran daring saat ini hanya dilakukan dengan penyampaian materi oleh guru saja dengan memberikan materi dalam bentuk file word atau dalam bentuk file power point, di masa pandemi ini media tersebut tidak menjamin proses pembelajaran berjalan efektif karena pemberian materi yang kurang menarik dan monoton sehingga peserta didik dalam memahami materi yang diajarkan masih merasa kesulitan maka dari itu kegiatan pembelajaran tersebut dirasa kurang mampu meningkatkan hasil belajar pada peserta didik.

Selain itu pembelajaran yang dilakukan hanya berdasarkan materi yang berasal dari guru saja (teacher oriented) pada Kurikulum 2013 Revisi ini menuntut siswa untuk lebih aktif (student oriented). Sedangkan pelaksanaan pembelajaran demikian tentu kurang mampu mendorong peserta didik untuk aktif dan mandiri dalam menemukan konsep bagi dirinya sendiri. Karena informasi hanya didapat dari guru saja tanpa ada kesempatan siswa untuk mencari sendiri informasi yang dibutuhkannya. 
Maka dari itu, peneliti bermaksud ingin membuat modul elektronik berbasis 3D PageFlip Professional yang mana sebagai bahan ajar untuk lebih memudahkan peserta didik dalam memahami materi yang akan disampaikan oleh pendidik. Dan dengan memanfaatkan teknologi pula agar peserta didik pun memahami bahwa belajar tidak hanya dengan buku saja, tetapi bisa dengan sumber yang lain tetapi ilmu yang didapat tetap sama dengan buku yang ada. Discovery Learning digunakan sebagai model pembelajaran untuk membuat peserta didik menjadi aktif dan mandiri yaitu dengan menemukan konsep sendiri untuk dirinya. Yang mana dari pembelajaran teacher oriented menjadi student oriented.

Penelitian yang sejalan juga dilakukan oleh Lumbantobing et al., (2019) Hasil penelitian menunjukkan produk e-modul untuk discovery learning pada materi tegangan dan poros telah memenuhi kriteria kelayakan dari segi materi, media maupun dari respon pengguna dengan kategori "sangat baik". Data penelitian menunjukkan bahwa ahli materi diperoleh penilaian emodul dengan kategori "sangat baik" dengan persentase kelayakan sebesar 95\%, dari ahli media diperoleh penilaian dengan kategori "sangat baik "dengan persentase kelayakan sebesar $82,86 \%$. Di samping itu, respon pengguna terhadap e-modul dalam hal ini guru dan siswa diperoleh kategori "sangat baik" dengan persentase kelayakan masing-masing adalah 84,38\% dan $81,67 \%$ yang menjelaskan bahwa e-modul dengan model discovery learning dinyatakan mampu meningkatkan minat belajar dan kemandirian belajar baik dari segi media, materi dan juga respon dari peserta didik dan memudahkan guru dalam menggunakan e-modul tersebut. Jadi bisa disimpulkan bahwa e-modul tersebut mampu meningkatkan hasil belajar peserta didik dan minat belajar.

\section{Metode}

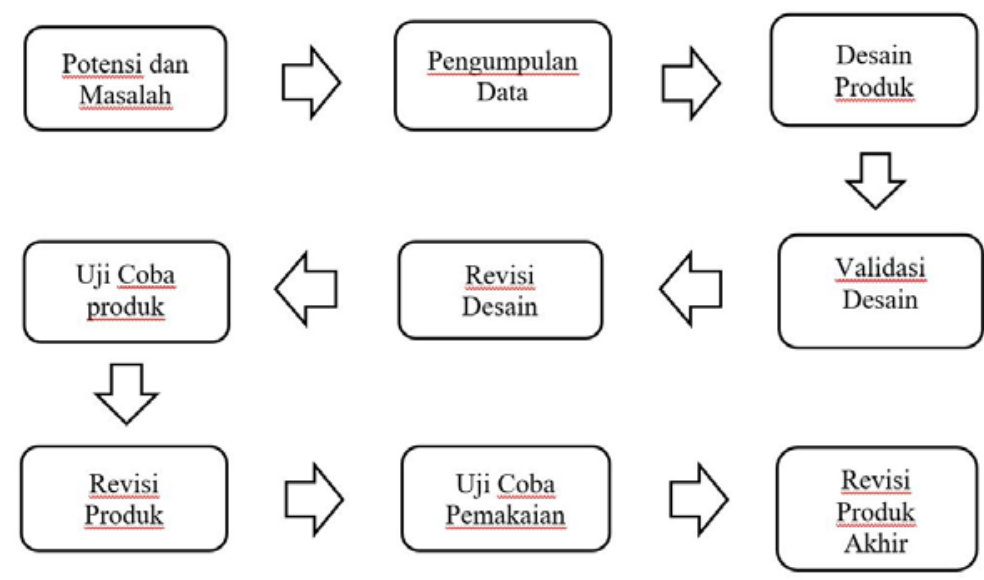

Gambar 1. langkah-langkah penelitian

Penelitian ini menggunakan model Research and Development Borg and Gall yang telah dimodifikasi menjadi sembilan langkah untuk mempersingkat waktu dan keadaan lapang. Selain itu, peneliti juga merasa bahwa tujuan penelitian yaitu untuk menghasilkan produk, mengetahui kelayakan produk, dan mengetahui perbedaan keterampilan kearsipan mahasiswa yang menggunakan dengan yang tidak menggunakan produk yang dikembangkan, sudah dapat tercapai di tahap kesembilan.

Langkah pertama, peneliti melakukan analisis potensi dan masalah terkait kegiatan pembelajaran mata pelajaran administrasi umum. Langkah kedua, peneliti mengumpulkan 
informasi terkait permasalahan yang terjadi di sekolah melalui wawancara, silabus dan daftar nilai kelas eksperimen dan kelas kontrol. Langkah ketiga, peneliti merancang produk media pembelajaran yang akan dikembangkan dan dapat menjadi solusi atas permasalahan yang ditemukan pada langkah potensi dan masalah serta pengumpulan informasi serta mulai membuat media pembelajaran sesuai rancangan yang telah ditentukan pada langkah sebelumnya. Langkah keempat, media yang dihasilkan peneliti diuji kelayakan oleh para validator, yakni satu ahli e-modul dan satu ahli materi. Langkah kelima, produk yang telah divalidasi direvisi berdasarkan masukan serta saran baik secara lisan maupun tulisan yang tertera pada lembar angket penilaian ahli materi dan ahli e-modul. Langkah keenam, produk yang telah direvisi diujicobakan pada 6 peserta didik yang menjadi uji coba kelompok kecil pada penelitian ini yaitu dari kelas eksperimen. Langkah ketujuh, produk yang telah diujicobakan pada kelompok kecil direvisi sesuai masukan-masukan siswa baik secara lisan maupun tulisan yang tertera pada lembar hasil angket uji coba kelompok kecil. Langkah kedelapan, produk yang telah direvisi kemudian diujicobakan pada kelompok besar yang melibatkan 18 peserta didik X OTKP 1 selaku kelas eksperimen sedangkan 18 Peserta Didik selaku kelas kontrol tetap menggunakan media pembelajaran dengan power point yang dilengkapi video pembelajaran. Langkah kesembilan, peneliti melakukan revisi apabila dalam uji coba kelompok besar masih terdapat kelemahan produk yang dikembangkan oleh peneliti.

Data yang dihasilkan pada penelitian ini meliputi data kualitatif dan data kuantitatif, dimana data data kuantitatif terdiri dari data hasil validasi ahli materi, data hasil validasi media, data hasil uji coba kelompok kecil, dan data nilai hasil belajar peserta didik kelas eksperimen dan kelas kontrol. Sedangkan data kualitatif didapatkan melalui penarikan kesimpulan berdasarkan pendapat secara umum, saran, dan kritik dari ahli materi, ahli media, dan 6 siswa uji coba kelompok kecil. Data hasil validasi ahli materi, ahli media, dan uji coba kelompok kecil dianalisis menggunakan metode deskriptif presentase untuk menunjukkan tingkat kelayakan media pembelajaran. Sedangkan data hasil belajar peserta didik dianalisis menggunakan uji normalitas, ketuntasan belajar dan uji independent sample t-test untuk menunjukkan perbedaan hasil belajar peserta didik pada kelas eksperimen dan kelas kontrol.

\section{Hasil dan Pembahasan}

Produk yang dihasilkan dalam penelitian dan pengembangan ini adalah e-modul berbasis 3D PageFlip Professional dengan Model Discovery Learning pada mata pelajaran administrasi umum pada kompetensi dasar bentuk-bentuk organisasi dan fungsi-fungsi manajemen. E-Modul Administrasi Umum yang ditampilkan melalui Gambar 2 berikut ini: 


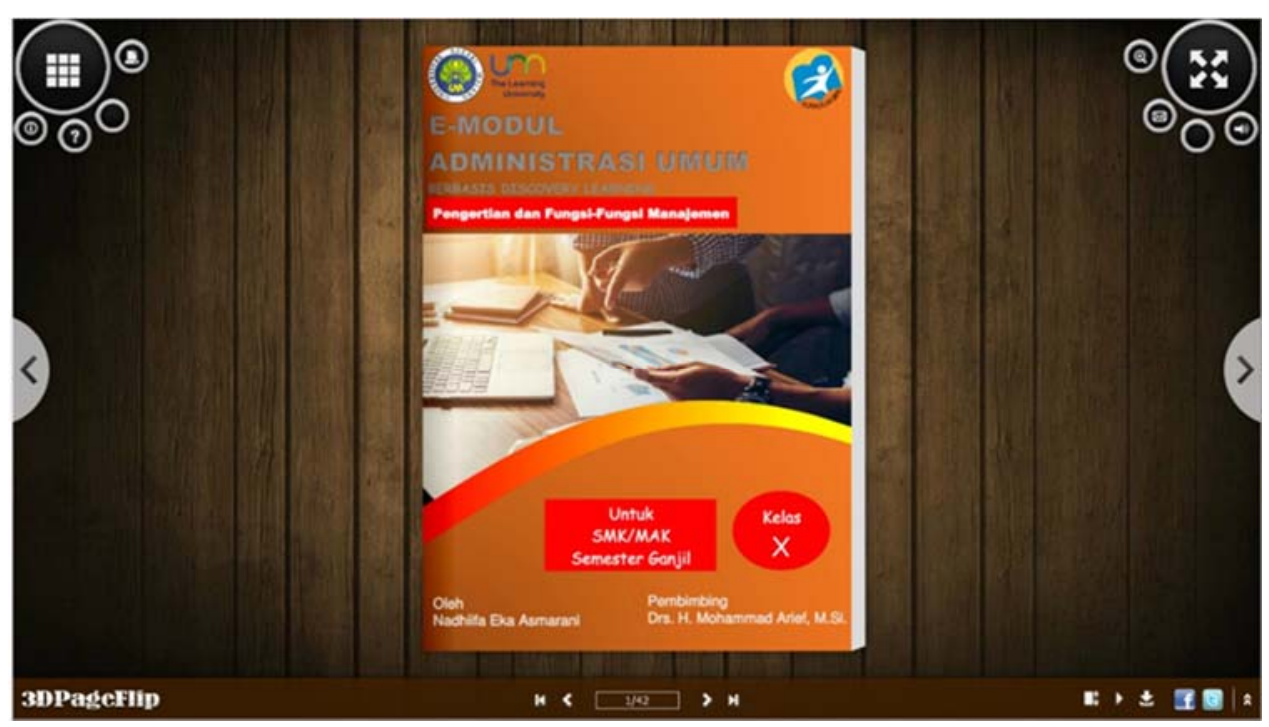

Hasil validasi E-Modul Administrasi Umum oleh ahli materi, ahli e-modul, dan siswa uji coba kelompok kecil secara keseluruhan disajikan dalam Tabel 1 berikut ini:

Tabel 1. data hasil validasi keseluruhan

\begin{tabular}{llll}
\hline No & Validasi & Persentase & Kriteria Validitas \\
\hline 1. & Ahli Materi & $96,78 \%$ & Sangat Valid \\
2. & Ahli E-Modul & $98,39 \%$ & Sangat Valid \\
3. & Uji Coba Kelompok Kecil & $84,82 \%$ & Sangat Valid \\
& Rata-rata & $93,34 \%$ & Sangat Valid \\
\hline
\end{tabular}

Table used by permission (c)Asmarani, Nadhiifa Eka 2021. Data hasil validasi keseluruhan.

Berdasarkan Tabel 1, diketahui rata-rata persentase validasi secara keseluruhan sebesar 93,34\%, sehingga dapat disimpulkan bahwa media pembelajaran yang dikembangkan peneliti yakni E-Modul Administrasi Umum, dinyatakan 'Sangat Valid' dan layak digunakan dalam pembelajaran Administrasi Umum di SMK Negeri 2 Kediri. Hal ini senada dengan penelitian sebelumnya, dimana hasil validasi ahli materi, ahli media dan uji coba kelompok kecil dijadikan dasar penentuan apakah media pembelajaran yang dikembangkan layak atau tidak digunakan dalam pembelajaran.

Titik pengukuran berupa validitas mengacu pada hasil pengukuran yang dilakukan untuk mengetahui seberapa banyak aspek dalam ranah kuantitatif pada instrumen pengukuran yang dinyatakan dengan skor. E-Modul Administrasi Umum dilengkapi dengan penyajian materi dan soal-soal dan terdapat menu yang berasal dari sintaks discovery learning yaitu Mari Mengamati, Mari Mengidentifikasi, Mari Mengumpulkan Data, Mari Mengolah Data, Mari Membuktikan dan Mari Menyimpulkan. Efisiensi dan penggunaan teknologi yang efektif tergantung pada ketersediaan perangkat keras dan perangkat lunak. Tampilan bagian model penyajian dan petunjuk penggunaan e-modul dapat dilihat pada Gambar 3. 

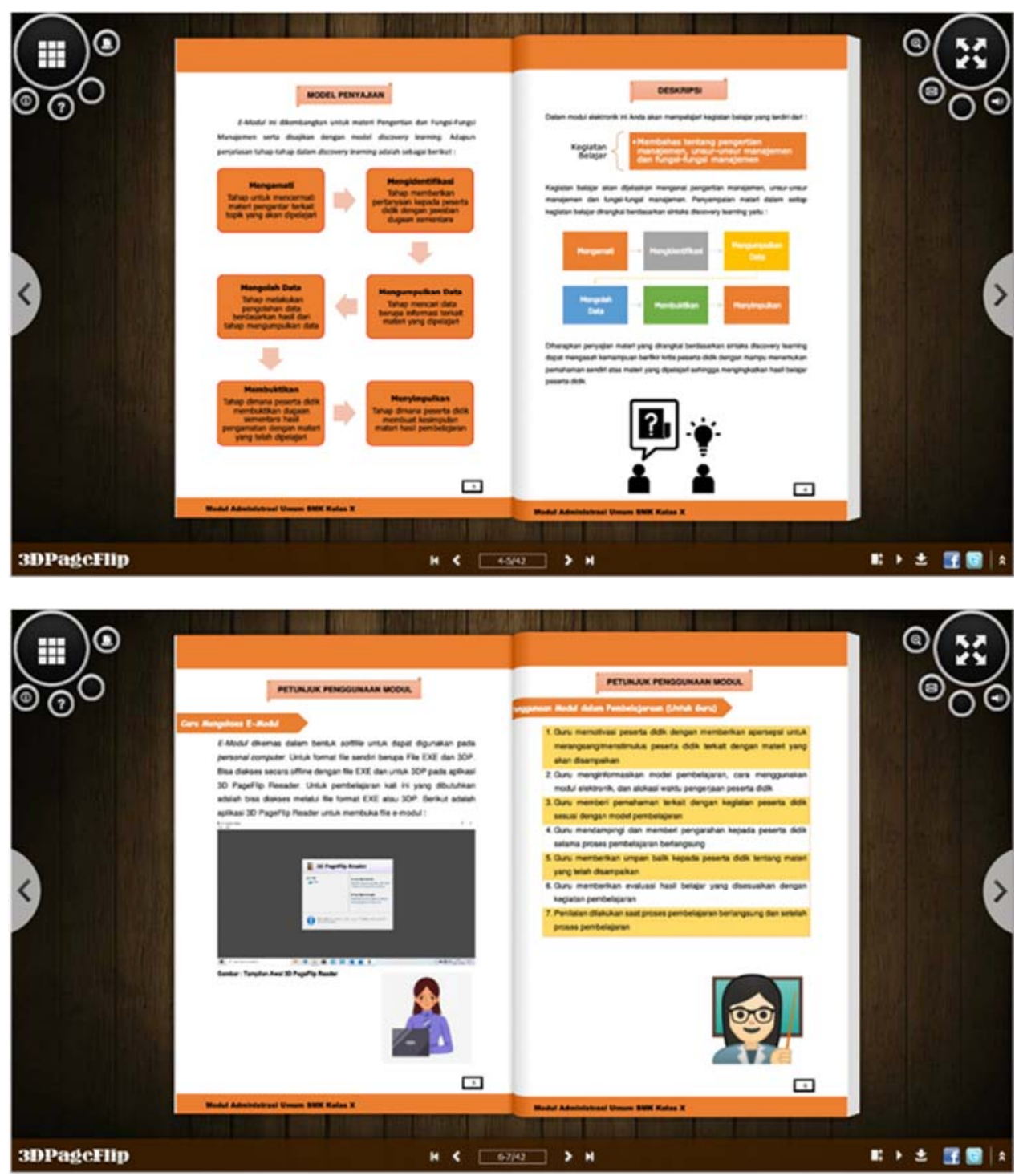

Gambar 3. Model Penyajian dan Petunjuk Penggunaan Modul

Sedangkan hasil uji independent sample t-test pada data peserta didik kelas kontrol dan kelas eksperimen disajikan dalam Tabel 2. Berdasarkan tabel output independent sample ttest pada bagian equal variances assumed diketahui nilai sig. (2-tailed) sebesar 0,000 >0,05, maka sebagaimana dasar pengambilan keputusan dalam uji independent sample t-test dapat disimpulkan bahwa HO ditolak dan Ha diterima. Dengan demikian dapat disimpulkan bahwa terdapat perbedaan yang signifikan antara rata-rata hasil belajar peserta didik pada posttest kelas eksperimen dan posttest kelas kontrol. Perbedaan hasil belajar peserta didik yang signifikan ini membuktikan bahwa penggunaan media pembelajaran yang dikembangkan peneliti efektif dapat meningkatkan hasil belajar peserta didik.

\section{Tabel 2. hasil uji independent sample t-test}

\begin{tabular}{l}
\hline Independent Samples Test \\
\hline Table used by permission (Asmarani, Nadhiifa Eka. 2021. Hasil uji independent samplet-test.
\end{tabular}


Jurnal Ekonomi, Bisnis dan Pendidikan, 1(1), 2021, 59-70

\begin{tabular}{|c|c|c|c|c|c|c|c|c|c|c|}
\hline & & \multicolumn{2}{|c|}{$\begin{array}{l}\text { Levene's } \\
\text { Test for } \\
\text { Equality of } \\
\text { Variances }\end{array}$} & \multicolumn{7}{|c|}{ t-test for Equality of Means } \\
\hline & & \multirow[t]{2}{*}{$\mathrm{F}$} & \multirow[t]{2}{*}{ Sig. } & \multirow[t]{2}{*}{$\mathrm{T}$} & \multirow[t]{2}{*}{$\mathrm{df}$} & \multirow[t]{2}{*}{$\begin{array}{l}\text { Sig. } \\
\text { (2- } \\
\text { tailed) }\end{array}$} & \multirow[t]{2}{*}{$\begin{array}{l}\text { Mean } \\
\text { Difference }\end{array}$} & \multirow[t]{2}{*}{$\begin{array}{l}\text { Std. Error } \\
\text { Difference }\end{array}$} & $\begin{array}{l}95 \% \\
\text { Confide } \\
\text { Interva } \\
\text { Differe }\end{array}$ & $\begin{array}{l}\text { ence } \\
\text { l of the } \\
\text { nce }\end{array}$ \\
\hline & & & & & & & & & Lower & Upper \\
\hline \multirow{2}{*}{$\begin{array}{l}\text { Hasil } \\
\text { belajar } \\
\text { peserta } \\
\text { didik }\end{array}$} & $\begin{array}{l}\text { Equal } \\
\text { variances } \\
\text { assumed }\end{array}$ & 1,242 & ,273 & 5,306 & 34 &, 000 & 9,333 & 1,759 & 5,758 & 12,908 \\
\hline & $\begin{array}{l}\text { Equal } \\
\text { variances } \\
\text { not } \\
\text { assumed }\end{array}$ & & & 5,306 & 32,612 & ,000 & 9,333 & 1,759 & 5,753 & 12,914 \\
\hline
\end{tabular}

Peningkatan hasil belajar peserta didik yang signifikan pada penelitian ini disebabkan oleh ketika melakukan praktik menggunakan media pembelajaran E-Modul Administrasi Umum, peserta didik lebih tertarik dan termotivasi untuk belajar secara mandiri. Selain itu adanya kemudahan dalam mengerjakan posttest dan tugas-tugas yang disediakan. Tampilan menu hingga soal pada E-Modul Administrasi Umum dapat dilihat pada Gambar 4.

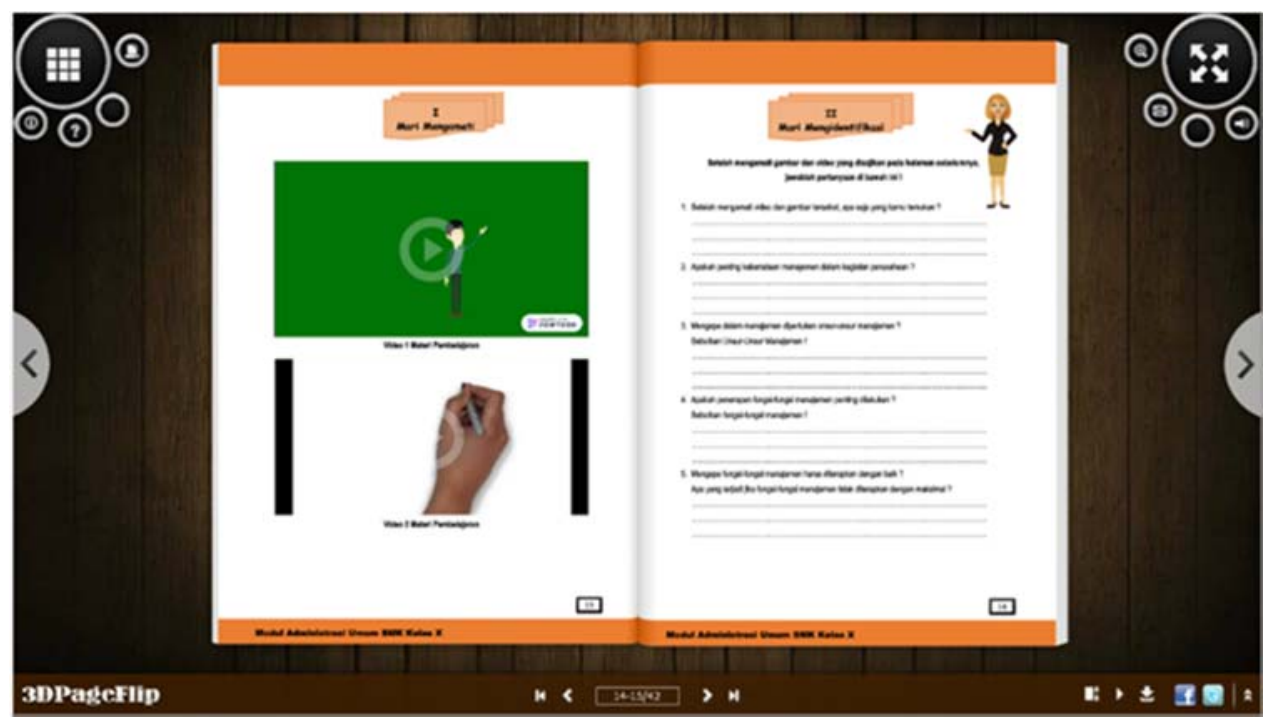



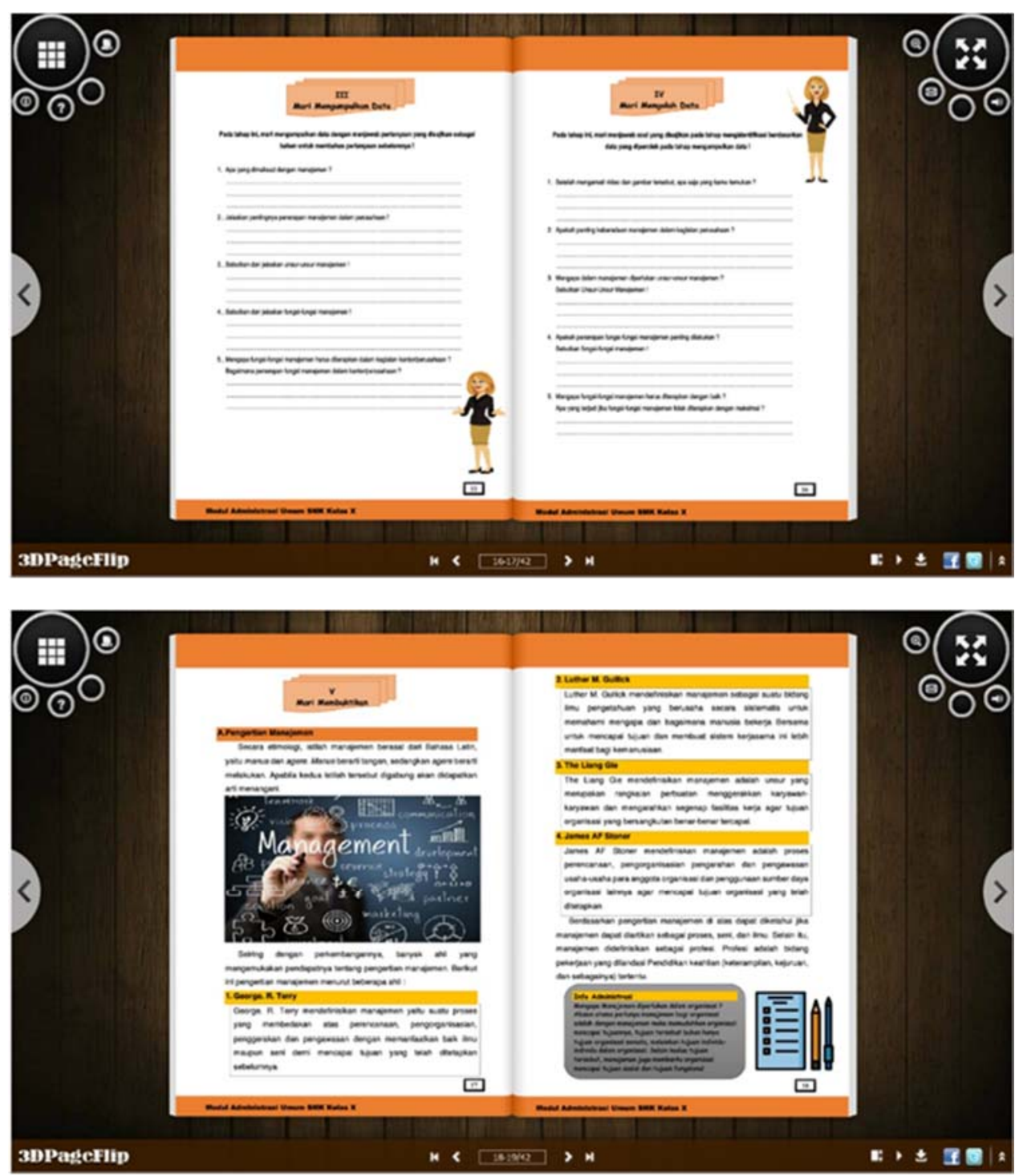

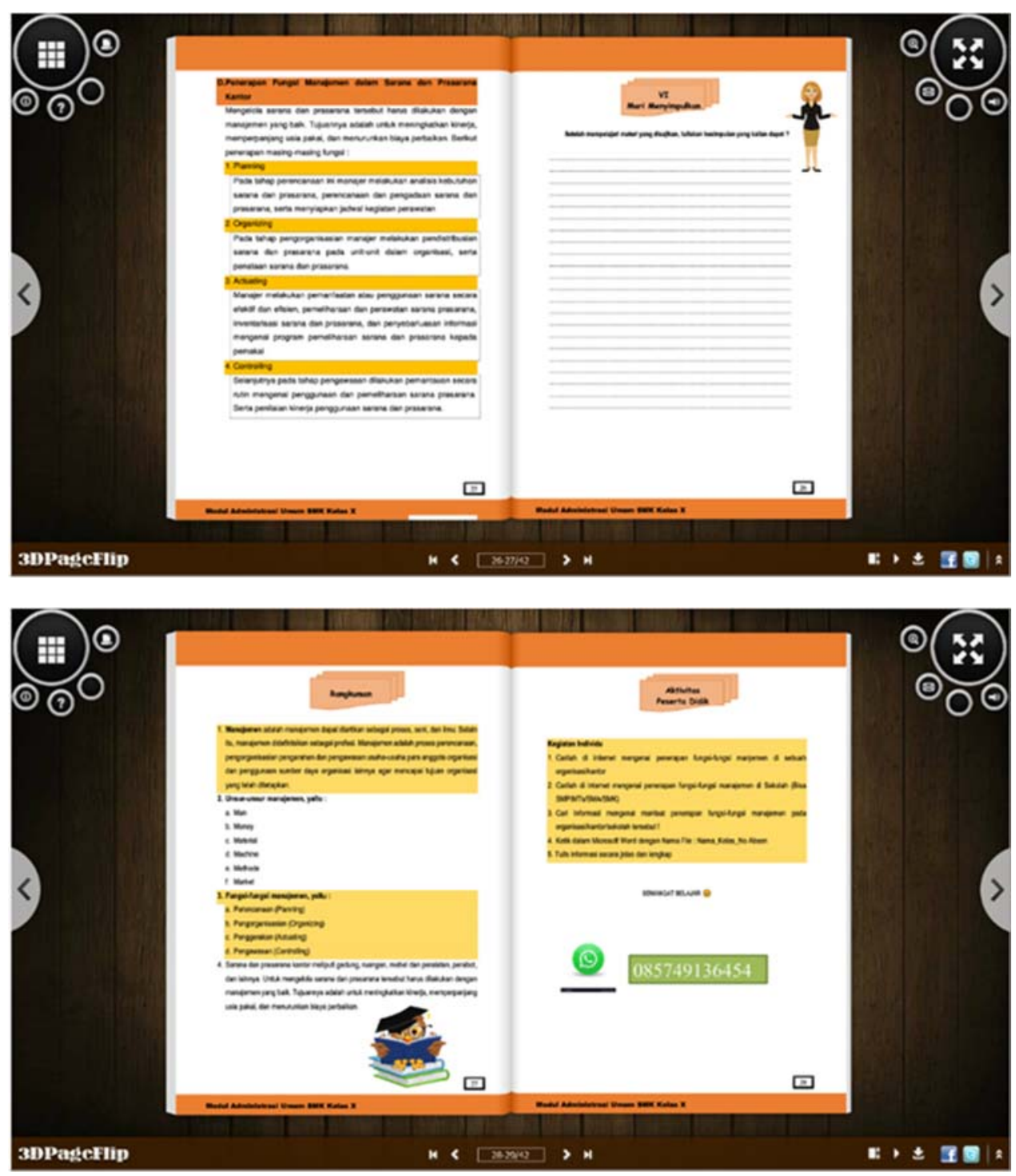


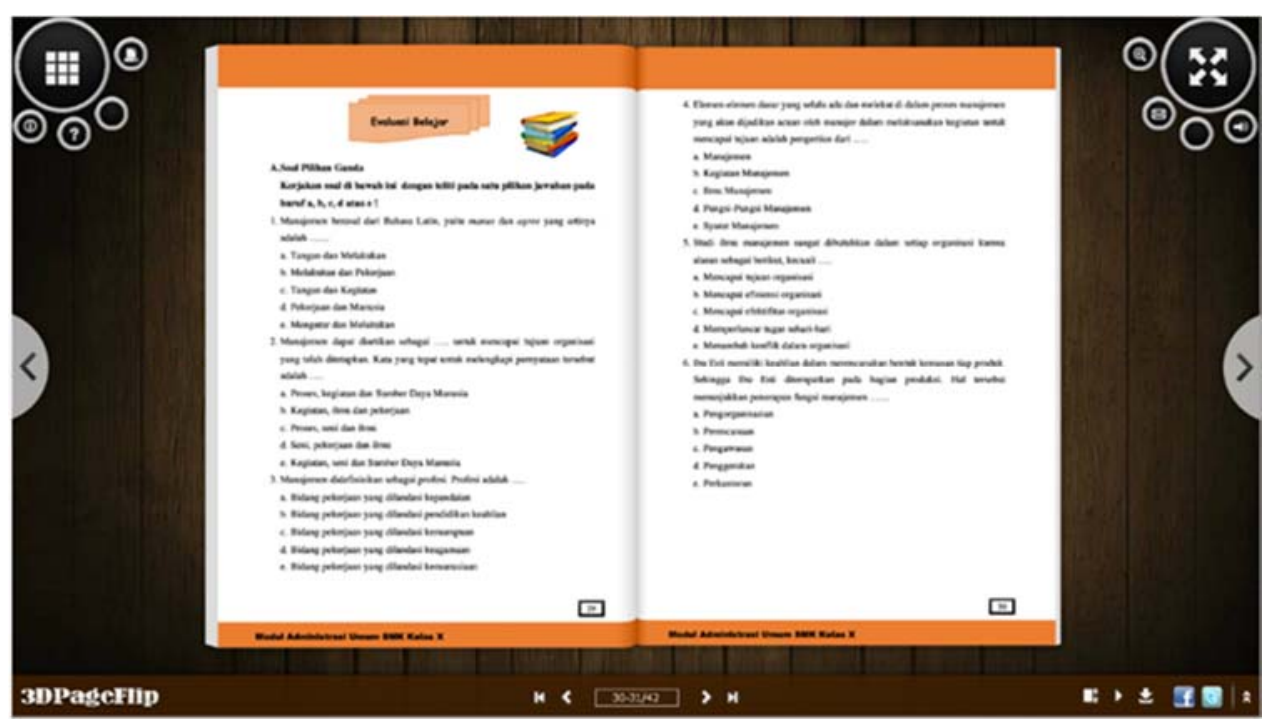

Gambar 4. Tampilan menu hingga evaluasi belajar

Selain itu adanya buku panduan, desain tampilan media pembelajaran yang menarik, gambar dengan kualitas yang baik, serta kualitas tampilan video yang baik, didapati mampu membuat kelas eksperimen menjadi lebih antusias dan tertarik dalam melakukan kegiatan belajar. Hasil belajar peserta didik meningkat pada kompetensi dasar fungsi-fungsi manajemen.

\section{Simpulan}

Penelitian dan pengembangan ini menghasilkan E-Modul Berbasis 3D PageFlip Professional dengan Model Discovery Learning pada Mata Pelajaran Administrasi Umum untuk meningkatkan hasil belajar peserta didik kompetensi dasar Bentuk Struktur Organisasi dan Fungsi-Fungsi Manajemen pada peserta didik kelas X OTKP 1 dan X OTKP 2 di SMK Negeri 2 Kediri. Media pembelajaran ini dapat akses secara online dengan menggunakan HP Android atau offline dengan Laptop/Personal Computer dengan Bantuan aplikasi 3D PageFlip Reader. Media pembelajaran pada penelitian ini telah dinyatakan 'Sangat Valid' dan layak digunakan dalam pembelajaran melalui validasi oleh ahli materi, ahli media serta uji coba kelompok kecil. Selain itu, E-Modul ini telah terbukti efektif dapat meningkatkan keterampilan kearsipan mahasiswa pada uji coba kelompok besar berdasarkan hasil uji independent sample t-test. SIEREN ini juga memungkinkan pembelajaran kapanpun dan dimanapun, bahkan secara mandiri tanpa harus terikat dengan kegiatan tatap muka di sekolah, sehingga e-modul ini berguna ketika pembelajaran tidak dapat dilakukan dengan bertatap muka secara langsung seperti saat terjadi akibat adanya pandemi covid-19. E-Modul Administrasi Umum hanya berfokus pada materi dan terbatas pada 2 kompetensi dasar saja, sehingga diharapkan peneliti selanjutnya untuk mengembangkan media pembelajaran pada mata pelajaran dan kompetensi dasar lainnya dan mempunyai kreativitas dalam desain yang lebih baik agar media pembelajaran yang dihasilkan lebih interaktif dan menarik.

\section{Daftar Rujukan}

Anggereini, E., (2017). Pengembangan E- Modul Pembelajaran Lingkungan Hidup Terintegrasi Nilai-Nilai Perilaku Pro Environmental dengan Aplikasi 3D Pageflip Profesional untuk Siswa SMA Sebagai Upaya Menjaga Lingkungan Hidup Berkelanjutan (Sustainable Environment). Biodik 3, 81-91. https://doi.org/10.22437/bio.v3i2.5499, diakses 10 Agustus 2020 
Asyhar, R., Afrida, A., \& Widiastiningsih, W. (2015). Pengembangan E-Modul Menggunakan Software 3D Pageflip Professional untuk Pembelajaran Ikatan Kimia Kelas X SMA Islam Al Falah Kota Jambi. Journal of The Indonesian Society of Integrated Chemistry, 7(1), 18-24, diakses 15 Agustus 2020

Churiyah, M., Safitri, A.A., Sutjipto, B.E., (2020). Collage Students' usage of E-Module Practicum for Increase SRL. Int. J. Sci. 54, 16.

Dinata, A. A., \& Zainul, R. (2020). Development of Discovery Learning Based E-Module on Buffer Solution Topic for Class XI Senior High School (SMA/MA). Edukimia, 2(1), 6-11., diakses 5 Agustus 2020

Fitri, H., Maison, M., \& Kurniawan, D. A. (2019). Pengembangan E-Modul Menggunakan 3D Pageflip Professional Pada Materi Momentum dan Impuls SMA/MA Kelas XI. Edufisika: Jurnal Pendidikan Fisika, 4(01), 46-58., diakses 20 Agustus 2020

Ghaliyah, S., Bakri, F., \& Siswoyo, S. (2015, October). Pengembangan modul elektronik berbasis model learning cycle 7E pada pokok bahasan fluida dinamik untuk siswa SMA kelas XI. In Prosiding Seminar Nasional Fisika (E-Journal) (Vol. 4, pp. SNF2015-II), diakses 5 September 2020

Hafsah, N. R., Rohendi, D., \& Purnawan, P. (2016). Penerapan media pembelajaran modul elektronik untuk meningkatkan hasil belajar siswa pada mata pelajaran teknologi mekanik. Journal of Mechanical Engineering Education, 3(1), 106-112. https://doi.org/10.17509/jmee.v3i1.3200, diakses 20 September 2020

Isnaeni, I., Agustina, Y., (2018). An Increase in Learning Outcome Students Is Through the Development Of Archive E-Module Based On The Flipbook With Discovery Learning Model. J. Pendidik. Bisnis Dan Manaj. 4,125-129. https://doi.org/10.17977/um003v4i32018p12, diakses 10 September 2020

Lumbantobing, M.A., Munadi, S., Wijanarka, B.S., (2019). Pengembangan E-Modul Interaktif untuk Discovery Learning pada Pembelajaran Mekanika Teknik dan Elemen Mesin. J. Din. Vokasional Tek. Mesin 4, 1-8. https://doi.org/10.21831/dinamika.v4i1.24275, diakses 11 September 2020

Munthe, E.A., Silaban, S., Muchtar, Z., (2019). Discovery Learning Based E-Module on Protein Material Development, in: Proceedings of the 4th Annual International Seminar on Transformative Education and Educational Leadership (AISTEEL 2019). Presented at the Proceedings of the 4th Annual International Seminar on Transformative Education and Educational Leadership (AISTEEL 2019), Atlantis Press, Medan City, Indonesia. https://doi.org/10.2991/aisteel-19.2019.137, diakses 15 September 2020

Nasution, M. K. (2018). Penggunaan metode pembelajaran dalam peningkatan hasil belajar siswa. Studia Didaktika, 11(01), 9-16. Diakses 25 September 2020

Nopriyanti, N., (2018). Pengembangan Modul Elektronik Berbasis 3D Pageflip Professional Mata Kuliah Gambar Teknik di Program Studi Pendidikan Teknik Mesin. J. Din. Vokasional Tek. Mesin 3, 64-75. https://doi.org/10.21831/dinamika.v3i1.19125, diakses 29 September 2020

Nugraha, A. (2015). Penggunaan e-module pembelajaran pada konsep sifat koligatif larutan untuk mengembangkan kemampuan literasi kimia siswa: penelitian kelas terhadap siswa kelas XI F 2 SMK Farmasi As-shifa Ciparay (Doctoral dissertation, UIN Sunan Gunung Djati Bandung), diakses 15 September 2020

Nurcahyo, E., \& Djono, D. (2018). The Implementation of Discovery Learning Model with Scientific Learning Approach to Improve Students' Critical Thinking in Learning History. Int. J. Multicult. Multireligious Underst. 5, 106. https://doi.org/10.18415/ijmmu.v5i3.234

Oktaviani, W., Gunawan, G., \& Sutrio, S. (2017). Pengembangan Bahan Ajar Fisika Kontekstual Untuk Meningkatkan Penguasaan Konsep Siswa. Jurnal Pendidikan Fisika dan Teknologi, 3(1), 1-7. https://doi.org/10.29303/jpft.v3i1.320, diakses 20 September 2020

Ong, M. H. A., \& Puteh, F. (2017). Quantitative Data Analysis: Choosing Between SPSS, PLS and AMOS in Social Science Research. International Interdisciplinary Journal of Scientific Research, 3(1), 14-25. (Online), (http://www.researchgate.net/publication/322885790_Quantitative_Data_Analysis_Choosing_Betwe en_SPSS_PLS_and_AMOS_in_Social_Science_Research) Diakses 26 November 2020.

Prasetiyo, N.A., Perwiraningtyas, P., (2017). The Development of Environment based Textbook in Biology Course at Tribhuwana Tunggadewi University. J. Pendidik. Biol. Indones. 3, 19. https://doi.org/10.22219/jpbi.v3i1.3969, diakses 10 September 2020

Priyanthi, K. A., Agustini, K., Santyadiputra, G. S., \& ST, M. C. (2017). Pengembangan E-Modul Berbantuan Simulasi Berorientasi Pemecahan Masalah Pada Mata Pelajaran Komunikasi Data (Studi Kasus: Siswa 
Kelas XI TKJ SMK Negeri 3 Singaraja). KARMAPATI (Kumpulan Artikel Mahasiswa Pendidikan Teknik Informatika), 6(1), 40-49, diakses 11 September 2020

Putri, F. E., Wijoyo, S. H., \& Wardhono, W. S. (2019). Pengaruh Media Pembelajaran Terhadap Minat Belajar dan Motivasi Belajar Yang Akan Berdampak Pada Hasil Belajar Peserta Didik Kelas XI Dalam Pembelajaran Produktif Jurusan Multimedia (Studi Kasus: SMK Negeri 11 Malang). Jurnal Pengembangan Teknologi Informasi dan Ilmu Komputer e-ISSN, 2548, 964X. Diakses 11 September 2020.

Raihan, S., Haryono, H., \& Ahmadi, F. (2018). Development of Scientific Learning E-Book Using 3D Pageflip Professional Program. Innovative Journal of Curriculum and Educational Technology, 7(1), 7-14.

Rudibyani, R.B., (2018). The Effectiveness of Discovery Learning to Improve Critical Thinking Skills College Student on Mastery of Arrhenius Acid Base. Sci. Eng. Educ. Dev. Stud. SEEDS Conf. Ser. 2. https://doi.org/10.20961/seeds.v2i1.24310

Siregar, A.F., (2020). Development of Learning Devices Based on Guided Discovery to Improve Students' Mathematical Reasoning Ability and Self-Esteem. J. Educ. Pract. https://doi.org/10.7176/JEP/11-3-12, diakses 4 September 2020

Weda, K.S., Agustini, K., Sugihartini, N., (2019). Pengaruh E-Modul Berbasis Discovery Learning Pada Mata Pelajaran Sistem Komputer Terhadap Hasil Belajar Siswa Kelas X Smk Negeri 3 Singaraja. J. Nas. Pendidik. Tek. Inform. Janapati 7, 141. https://doi.org/10.23887/janapati.v7i2.13349, diakses 10 September 2020

Winatha, K.R., (2018). Pengembangan E-modul Interaktif Berbasis Proyek Mata Pelajaran Simulasi Digital. J. Pendidik. Teknol. Dan Kejuru. 15. https://doi.org/10.23887/jptk-undiksha.v15i2.14021, diakses 20 September 2020

Yelianti, U., Muswita, M., Sanjaya, M.E., (2018). Development of Electronic Learning Media Based 3D Pageflip on Subject Matter of Photosynthetis in Plant Physiology Course. BIODIK 4, 121-134. https://doi.org/10.22437/bio.v4i2.5858, diakses 30 Agustus 2020 